\title{
Structure and Function of Immunoglobulins
}

\author{
Harry W Schroeder Jr, M.D., Ph.D. ${ }^{1 \dagger}$ and Lisa Cavacini, Ph.D. ${ }^{2}$ \\ ${ }^{1}$ Division of Clinical Immunology and Rheumatology, Departments of Medicine, Microbiology, and \\ Genetics, University of Alabama at Birmingham, Mailstop: SHEL176, USPS address: $15303^{\text {rd }}$ \\ Avenue South, Courier address: 1825 University Boulevard, Birmingham, AL 35294-2182, Phone: \\ (205) 934-1522, FAX: (205) 975-6352 hwsj@uab.edu
}

${ }^{2}$ Department of Medicine, Beth Israel Deaconess Medical Center, Mailstop: RN390, 330

Brookline Avenue, Boston, MA 02215, Phone: (617) 667-8817, FAX: (617) 667-8820

Icavacin@bidmc.harvard.edu

\begin{abstract}
Immunoglobulins are heterodimeric proteins composed of two heavy $(\mathrm{H})$ and two light $(\mathrm{L})$ chains. They can be separated functionally into variable (V) domains that binds antigens and constant (C) domains that specify effector functions such as activation of complement or binding to $\mathrm{Fc}$ receptors. The variable domains are created by means of a complex series of gene rearrangement events, and can then be subjected to somatic hypermutation after exposure to antigen to allow affinity maturation. Each V domain can be split into three regions of sequence variability, termed the complementarity determining regions, or CDRs, and four regions of relatively constant sequence termed the framework regions, or FRs. The three CDRs of the $\mathrm{H}$ chain are paired with the three CDRs of the L chain to form the antigen binding site, as classically defined. There are five main classes of heavy chain $\mathrm{C}$ domains. Each class defines the $\operatorname{IgM}, \operatorname{IgG}, \operatorname{IgA}$, $\operatorname{IgD}$, and $\operatorname{IgE}$ isotypes. $\operatorname{IgG}$ can be split into four subclasses, $\mathrm{IgG1}, \operatorname{IgG} 2, \mathrm{IgG} 3$, and $\mathrm{IgG} 4$, each with its own biologic properties; and IgA can similarly be split into IgA1 and IgA2. The constant domains of the $\mathrm{H}$ chain can be switched to allow altered effector function while maintaining antigen specificity.
\end{abstract}

\section{Keywords}

Antibody structure; Antibody function; Immunoglobulin structure; Immunoglobulin function; Immunoglobulin gene rearrangement; Class switching; Somatic hypermutation

\section{Introduction}

In 1890, von Behring and Kitasato reported the existence of an agent in the blood that could neutralize diphtheria toxin. The following year, reference was made to 'Antikörper', or antibodies, in studies describing the ability of the agent to discriminate between two immune substances. Subsequently, the substance which induces the production of an antibody was referred to as the 'Antisomatogen+Immunkörperbildner', or that agent which induces the antibody. The term antigen is a contraction of this term. Thus, an antibody and its antigen represent a classic tautology.

In 1939, Tiselius and Kabat used electrophoresis to separate immunized serum into albumin, alpha-goblulin, beta-globulin, and gamma-globulin fractions. Absorption of the serum

${ }^{\dagger}$ Corresponding Author. 
against the antigen depleted the gamma-globulin fraction, yielding the terms gamma globulin, immunoglobulin (Ig), and IgG. "Sizing" columns were then used to separate immunoglobulins into those that were "heavy" (IgM), "regular" (IgA, IgE, IgD, IgG), and "light" (light chain dimers).

More than 100 years of investigation into the structure and function of immunoglobulin has only served to emphasize the complex nature of this protein. Typically, receptors bind to a limited and defined set of ligands. However, while individual immunoglobulin also bind a limited and defined set of ligands, immunoglobulins as a population can bind to a virtually unlimited array of antigens sharing little or no similarity. This property of adjustable binding depends on a complex array of mechanisms that alter the DNA of individual B cells. Immunoglobulins also serve two purposes: that of cell-surface receptors for antigen which permit cell signaling and cell activation and that of soluble effector molecules which can individually bind and neutralize antigens at a distance. The molecular mechanisms that permit these many and varied functions are the focus of this chapter.

\section{Structural elements}

\section{The immunoglobulin domain: the basic IgSF building block}

Immunoglobulins (Igs) belong to the eponymous immunoglobulin super-family (IgSF). ${ }^{(1-3)}$ They consist of two heavy $(\mathrm{H})$ and two light (L) chains (Figure 1), where the L chain can consist of either a $x$ or a $\lambda$ chain. Each component chain contains one NH2-terminal "variable (V) IgSF domain and one or more COOH-terminal "constant" (C) IgSF domains, each of which consists of two sandwiched $\beta$ pleated sheets 'pinned' together by a disulfide bridge between two conserved cysteine residues. ${ }^{(1)}$ Each $\mathrm{V}$ or $\mathrm{C}$ domain consists of approximately 110-130 amino acids, averaging 12,000-13,000 kDa. Both Ig L chains contain only one $\mathrm{C}$ domain, whereas Ig $\mathrm{H}$ chains contain either three or four such domains. $\mathrm{H}$ chains with three $\mathrm{C}$ domains tend to include a spacer hinge region between the first $\left(\mathrm{C}_{\mathrm{H}} 1\right)$ and second $\left(\mathrm{C}_{\mathrm{H}} 2\right)$ domains. A typical $\mathrm{L}$ chain will thus mass approximately $25 \mathrm{kDa}$, and a three $\mathrm{C}$ domain $\mathrm{C} \gamma \mathrm{H}$ chain with its hinge will mass approximately $55 \mathrm{kDa}$. Considerable variability is allowed to the amino acids that populate the external surface of the IgSF domain and to the loops that link the $\beta$ strands. These solvent exposed surfaces offer multiple targets for docking with other molecules.

\section{Antigen Recognition and the Fab}

Early studies of Ig structure were facilitated by the use of enzymes to fragment $\operatorname{IgG}$ molecules. Papain digests IgG into two Fab fragments, each of which can bind antigen, and a single $\mathrm{Fc}$ fragment. Pepsin splits $\mathrm{IgG}$ into an $\mathrm{Fc}$ fragment and a single dimeric $\mathrm{F}(\mathrm{ab})_{2}$ that can cross-link as well as bind antigens. The Fab contains one complete $\mathrm{L}$ chain in its entirety and the $\mathrm{V}$ and $\mathrm{C}_{\mathrm{H}} 1$ portion of one $\mathrm{H}$ chain (Figure 1). The Fab can be further divided into a variable fragment $(\mathrm{Fv})$ composed of the $\mathrm{V}_{\mathrm{H}}$ and $\mathrm{V}_{\mathrm{L}}$ domains, and a constant fragment $(\mathrm{Fb})$ composed of the $C_{L}$ and $C_{H} 1$ domains. Single $F v$ fragments can be genetically engineered to recapitulate the monovalent antigen binding characteristics of the original, parent antibody. ${ }^{(4)}$

Intriguingly, a subset of antibodies in a minority of species [camelids (5), nurse shark (6)] lack light chains entirely and use only the heavy chain for antigen binding. While these unusual variants are not found in human, there are a number of ongoing attempts to humanize these types of antibodies for therapeutic and diagnostic purposes (e.g. (7)). 


\section{Paratopes, epitopes, idiotypes and isotypes}

Immunoglobulin-antigen interactions typically take place between the paratope, the site on the Ig at which the antigen binds, and the epitope, which is the site on the antigen that is bound. In vivo, immunoglobulins tend to be produced against intact antigens in soluble form, and thus preferentially identify surface epitopes that can represent conformational structures that are noncontiguous in the antigen's primary sequence. This ability to identify component parts of the antigen independently of the rest makes it possible for the B cell to discriminate between two closely related antigens, each of which can be viewed as a collection of epitopes. It also permits the same antibody to bind divergent antigens that share equivalent or similar epitopes, a phenomenon referred to as cross-reactivity.

Immunization of heterologous species with monoclonal antibodies (or a restricted set of immunoglobulins) allowed the identification of both common and individual immunoglobulin antigenic determinants. Individual determinant(s), termed idiotype(s), are contained within $\mathrm{V}$ domains. Common determinants, termed isotypes, are specific for the constant portion of the antibody and allow grouping of immunoglobulins into recognized classes, with each class defining an individual type of $\mathrm{C}$ domain. Determinants common to subsets of individuals within a species, yet differing between other members of that species, are termed allotypes and define inherited polymorphisms that result from gene alleles. ${ }^{(8)}$

\section{Immunoglobulin gene organization and rearrangement}

Ig heavy and light chains are each encoded by a separate multigene family, ${ }^{(9,10)}$ and the individual $\mathrm{V}$ and $\mathrm{C}$ domains are each encoded by independent elements: $\mathrm{V}(\mathrm{D}) \mathrm{J}$ gene segments for the $\mathrm{V}$ domain and individual exons for the $\mathrm{C}$ domains. The primary sequence of the $\mathrm{V}$ domain is functionally divided into three hypervariable intervals, termed complementarity determining regions (CDRs) that are situated between four regions of stable sequence termed frameworks (FRs) (Figure 1).

\section{Immunoglobulin rearrangement}

Each $\mathrm{V}$ gene segment typically contains its own promoter, a leader exon, an intervening intron, an exon that encodes the first three framework regions (FR 1,2, and 3), CDRs 1 and 2 in their entirety, the amino terminal portion of CDR 3, and a recombination signal sequence (RSS). Each J (for joining) gene segment begins with its own recombination signal, the carboxy terminal portion of CDR 3, and the complete FR 4 (Figure 1, Figure 2).

The creation of a V domain is directed by the recombination signal sequences (RSS) that flank the rearranging gene segments. Each RSS contains a strongly conserved seven base pair, or heptamer, sequence (e.g., CACAGTG) that is separated from a less well-conserved nine base pair, or nonamer, sequence (e.g., ACAAAACCC) by either a 12- or 23-base-pair spacer. These spacers place the heptamer and nonamer sequences on the same side of the DNA molecule, separated by either one or two turns of the DNA helix. A one turn recombination signal sequence (12 base pair spacer) will preferentially recognize a two turn signal sequence ( 23 base pair spacer), thereby avoiding wasteful V-V or J-J rearrangements.

Initiation of the $\mathrm{V}(\mathrm{D}) \mathrm{J}$ recombination reaction requires recombination activating genes 1 and 2 (RAG-1 and RAG-2), which are almost exclusively expressed in developing lymphocytes. ${ }^{(11)}$ RAG-1 and RAG-2 introduce a DNA double-strand break (DSB) between the terminus of the rearranging gene segment and its adjacent recombination signal sequence. These breaks are then repaired by ubiquitously expressed components of a DNA repair process, known as nonhomologous end-joining (NHEJ), that are common to all cells of the body. Thus, while mutations of RAG affect only lymphocytes, loss or alteration-offunction mutations in NHEJ proteins yield susceptibility to DNA damage in all cells of the 
body. The NHEJ process creates precise joins between the RSS ends, and imprecise joins of the coding ends. Terminal deoxynucleotidyl transferse (TdT), which is expressed only in lymphocytes, can variably add non-germline encoded nucleotides ( $\mathrm{N}$ nucleotides) to the coding ends of the recombination product.

Typically, the initial event in recombination will be recognition of 12-bp spacer RSS by RAG-1. RAG-2 then associates with RAG-1 and the heptamer to form a synaptic complex. Binding of a second RAG-1 and RAG-2 complex to the 23-bp, two-turn RSS permits the interaction of the two synaptic complexes to form what is known as a paired complex; a process that is facilitated by the actions of the DNA-bending proteins HMG1 and HMG2.

After paired complex assembly, the RAG proteins single strand cut the DNA at the heptamer sequence. The 3' $\mathrm{OH}$ of the coding sequence ligates to 5' phosphate and creates a hairpin loop. The clean cut ends of the signal sequences enable formation of precise signal joints. However, the hairpin junction created at the coding ends must be resolved by re-nicking the DNA, usually within four to five nucleotides from the end of the hairpin. This forms a 3 ' overhang that is amenable to further modification. It can be filled in via DNA polymerases, nibbled, or serve as a substrate for TdT-catalyzed $\mathrm{N}$ addition. DNA polymerase $\mu$, which shares homology with TdT, appears to play a role in maintaining the integrity of the terminus of the coding sequence.

The cut ends of the coding sequence are then repaired by the non-homologous end joining proteins. NHEJ proteins involved in V(D)J recombination include Ku70, Ku80, DNA-PKcs, Artemis, XRCC4, and ligase $4 . \mathrm{Ku} 70$ and $\mathrm{Ku} 80$ form a heterodimer $(\mathrm{Ku})$ that directly associates with DNA double-strand breaks to protect the DNA ends from degradation, permit juxtaposition of the ends to facilitate coding end ligation, and help recruit other members of the repair complex. DNA-PKcs phosphorylates Artemis, inducing an endonuclease activity that plays a role in the opening of the coding joint hairpin. Finally, XRCC4 and ligase 4 help rejoin the ends of the broken DNA. Deficiency of any one of these proteins creates sensitivity to DNA breakage and can lead to a SCID phenotype.

\section{The $\mathrm{k}$ locus}

The $\kappa$ locus is located on chromosome $2 \mathrm{p} 11.2 .^{(12)} \kappa \mathrm{V}$ domains represent the joined product of $\mathrm{V} \kappa$ and $\mathrm{J} \kappa$ gene segments (Figure 2), whereas the $\kappa \mathrm{C}$ domains is encoded by a single $\mathrm{C} \kappa$ exon. The locus contains five $\mathrm{J} \kappa$ and $75 \mathrm{~V} \kappa$ gene segments upstream of $\mathrm{C} \kappa$ (Figure 3). One third of the $\mathrm{V} \kappa$ gene segments contain frameshift mutations or stop codons that preclude them from forming functional protein, and of the remaining sequences less than 30 of the $\mathrm{V} \kappa$ gene segments have actually been found in functional immunoglobulins. $\mathrm{V}$ gene segments can be grouped into families on the basis of sequence and structural similarity. ${ }^{(13,14)}$ There are six such families for $\mathrm{V} \kappa$.

Each active $V \kappa$ gene segment has the potential to rearrange to any one of the five J $\kappa$ elements, generating a potential 'combinatorial' repertoire of more than 140 distinct VJ combinations. The V $\kappa$ gene segment contains FR $1,-2$, and -3 , CDR 1 and -2 , and the amino terminal portion of CDR3; whereas the Jא element contains the carboxy terminus of CDR3 and FR4 in its entirety. The terminus of each rearranging gene segment can undergo a loss of 1 to 5 nucleotides during the recombination process, yielding additional 'junctional' diversity. In human, TdT can introduce random $\mathrm{N}$ nucleotides to either replace some or all of the lost $\mathrm{V} \kappa$ or $\mathrm{J} \kappa$ nucleotides, or to add to the original germline sequence. ${ }^{(15)}$ Each codon created by $\mathrm{N}$ addition increases the potential diversity of the repertoire 20 -fold. Thus, the initial diversification of the $\mathrm{x}$ repertoire is focused at the $\mathrm{VJ}$ junction that defines the light chain CDR3, or CDR-L3. 


\section{The $\lambda$ locus}

The $\lambda$ locus, on chromosome 22q11.2, contains four functional $C \lambda$ exons, each of which is associated with its own $\mathrm{J} \lambda$ (Figure 3). V $\lambda$ genes are arranged in three distinct clusters, each containing members of different $\mathrm{V} \lambda$ families. ${ }^{(16)}$ Depending on the individual haplotype, there are approximately 30-36 potentially functional $\mathrm{V} \lambda$ gene segments and an equal number of pseudogenes.

During early B cell development, $\mathrm{H}$ chains form a complex with unconventional $\lambda$ light chains, known as surrogate or pseudo light chains ( $\Psi L C)$, to form a pre-B cell receptor. The genes encoding the $\Psi$ LC proteins, $\lambda 14.1$ ( $\lambda 5)$ and $\mathrm{V}_{\text {preB }}$, are located within the $\lambda$ light chain locus on chromosome 22 . Together, these two genes create a product with considerable homology to conventional $\lambda$ light chains. A critical difference between these unconventional $\Psi$ LC genes and other $\mathrm{L}$ chains is that 14.1 and $\mathrm{V}_{\text {preB }}$ gene rearrangement is not required for $\Psi$ LC expression. The region of the $\Psi$ LC that corresponds to CDR-L3 covers $\mathrm{CDR}-\mathrm{H} 3$ in the pre-B cell receptor, allowing the pre-B cell to avoid antigen-specific selection.(17)

\section{The $\mathrm{H}$ chain locus}

The $\mathrm{H}$ chain locus, on chromosome $14 \mathrm{q} 32.33$, is considerably more complex than the light chain clusters. The $\sim 80 \mathrm{~V}_{\mathrm{H}}$ gene segments near the telomere of the long arm of chromosome 14 can be grouped into seven different families of related gene segments. ${ }^{(18)}$ Of these, approximately 39 are functional. Adjacent to the most centromeric $\mathrm{V}_{\mathrm{H}}$, V6-1, are $27 \mathrm{D}_{\mathrm{H}}(\mathrm{D}$ for diversity) gene segments (Figure 3) ${ }^{(19)}$ and six $\mathrm{J}_{\mathrm{H}}$ gene segments. Each $\mathrm{V}_{\mathrm{H}}$ and $\mathrm{J}_{\mathrm{H}}$ gene segment is associated with a two turn recombination signal sequence, which prevents direct $\mathrm{V}->\mathrm{J}$ joining. A pair of one turn recombination signal sequences flanks each $\mathrm{D}_{\mathrm{H}}$. Recombination begins with the joining of a $D_{H}$ to a $J_{H}$ gene segment, followed by the joining of a $\mathrm{V}_{\mathrm{H}}$ element to the amino terminal end of the DJ intermediate. The $\mathrm{V}_{\mathrm{H}}$ gene segment contains FR1, -2 , and -3 , CDR 1 and -2 , and the amino terminal portion of CDR3; the $\mathrm{D}_{\mathrm{H}}$ gene segment forms the middle of CDR3; and the $\mathrm{J}_{\mathrm{H}}$ element contains the carboxy terminus of CDR3 and FR4 in its entirety (Figure 1). Random assortment of one of $\sim 50$ active $\mathrm{V}_{\mathrm{H}}$ and one of $27 \mathrm{D}_{\mathrm{H}}$ with one of the six $\mathrm{J}_{\mathrm{H}}$ gene segments can generate more than $10^{4}$ different VDJ combinations (Figure 4).

While combinatorial joining of individual $\mathrm{V}, \mathrm{D}$, and $\mathrm{J}$ gene segments maximizes germlineencoded diversity, the junctional diversity created by VDJ joining is the major source of variation in the pre-immune repertoire (Figure 4). First, $D_{H}$ gene segments can rearrange by either inversion or deletion, and each $\mathrm{D}_{\mathrm{H}}$ can be spliced and translated in each of the three potential reading frames. This gives each $\mathrm{D}_{\mathrm{H}}$ gene segment the potential to encode six different peptide fragments. Second, the rearrangement process proceeds through a step that creates a hairpin ligation between the 5' and 3' termini of the rearranging gene segment. Nicking to resolve the hairpin structure leaves a 3' overhang that creates a palindromic extension, termed a $\mathrm{P}$ junction. Third, the terminus of each rearranging gene segment can undergo a loss of one to several nucleotides during the recombination process. Fourth, TdT can add numerous $\mathrm{N}$ nucleotides to replace or add to the original germline sequence. $\mathrm{N}$ nucleotides can be inserted between the $\mathrm{V}$ and the $\mathrm{D}$, as well as between the $\mathrm{D}$ and the $\mathrm{J}$. The imprecision of the joining process and variation in the extent of $\mathrm{N}$ addition permits generation of CDR-H3s of varying length and structure. As a result, more than $10^{10}$ different $\mathrm{H}$ chain VDJ junctions, or CDR-H3s, can be generated at the time of gene segment rearrangement. Taken as a whole, somatic variation in CDR3, combinatorial rearrangement of individual gene segments and combinatorial association between different $\mathrm{L}$ and $\mathrm{H}$ chains can yield a potential pre-immune antibody repertoire of greater than $10^{16}$ different immunoglobulins. 


\section{Class switch recombination (CSR)}

Located downstream of the VDJ loci are nine functional CH genes (Figure 3). ${ }^{(20)}$ These constant genes consist of a series of exons, each encoding a separate domain, hinge, or terminus. All $\mathrm{CH}$ genes can undergo alternative splicing to generate two different types of carboxy termini: either a membrane terminus that anchors immunoglobulin on the B lymphocyte surface or a secreted terminus that occurs in the soluble form of the immunoglobulin. With the exception of $\mathrm{C}_{\mathrm{H}} 1 \delta$, each $\mathrm{C}_{\mathrm{H}} 1$ constant region is preceded by both an exon that cannot be translated (an I exon) and a region of repetitive DNA termed the switch (S). Cocktails of cytokine signals transmitted by T cells or other extracellular influences variably activate the I exon, initiating transcription and thus activating the gene. Through recombination between the $\mathrm{C} \mu$ switch region and one of the switch regions of the seven other $\mathrm{H}$ chain constant regions (a process termed class switching or class switch recombination [CSR]), the same VDJ heavy chain variable domain can be juxtaposed to any of the $\mathrm{H}$ chain classes. ${ }^{(20)}$ This enables the $\mathrm{B}$ cell to tailor both the receptor and the effector ends of the antibody molecule to meet a specific need.

\section{Somatic hypermutation (SHM)}

A final mechanism of immunoglobulin diversity is engaged only after exposure to antigen. With $\mathrm{T}$ cell help, the variable domain genes of germinal center lymphocytes undergo somatic hypermutation (SHM) at a rate of up to $10^{-3}$ changes per base pair per cell cycle. SHM is correlated with transcription of the locus and in human two separate mechanisms are involved: the first mechanism targets mutation hot spots with the RGYW (purine/G/ pyrimidine/A) motif ${ }^{(21)}$ and the second mechanism incorporates an error-prone DNA synthesis that can lead to a nucleotide mismatch between the original template and the mutated DNA strand. ${ }^{(22)}$ Other species use gene conversion between functional and nonfunctional V sequences to introduce additional somatic diversity. SHM allows affinity maturation of the antibody repertoire in response to repeated immunization or exposure to antigen.

\section{Activation-induced cytidine deaminase (AID)}

AID plays a key role in both CSR and SHM. ${ }^{(11,23)}$ AID is a single strand DNA (ssDNA) cytidine deaminase that can be expressed in activated germinal center B cells.(24) Transcription of an immunoglobulin $\mathrm{V}$ domain or of the switch region upstream of the $\mathrm{C}_{\mathrm{H}} 1$ domain opens the DNA helix to generate ssDNA that can then be deaminated by AID to form mismatched dU/dG DNA base pairs. The base excision repair protein uracil DNA glycosylase (UNG) removes the mismatched dU base, creating an abasic site. Differential repair of thie lesion leads to either SHM or CSR. The mismatch repair (MMR) proteins MSH2 and MSH6 can also bind and process the dU:dG mismatch. Deficiencies of AID, UNG underlie some forms of the hyper-IgM syndrome.

\section{Generation of immunoglobulin diversity occurs at defined stages of $B$ cell development}

Creation of immunoglobulin diversity is hierarchical. In pro-B cells, $\mathrm{D}_{\mathrm{H}} \rightarrow \mathrm{J}_{\mathrm{H}}$ joining precedes $\mathrm{V}_{\mathrm{H}} \rightarrow \mathrm{DJ}_{\mathrm{H}}$ rearrangement and $\mathrm{V}_{\mathrm{L}} \rightarrow \mathrm{J}_{\mathrm{L}}$ joining takes place at the late pre-B cell stage. Production of a properly functioning $\mathrm{B}$ cell receptor is essential for development beyond the pre-B cell stage. For example, function-loss mutations in RAG-1/2 and DNA dependent protein kinase (DNA-PKcs, Ku 70/80) preclude B cell development, as well as T cell development, leading to severe combined immune deficiency. In-frame, functional $\mathrm{VDJ}_{\mathrm{h}}$ rearrangement allows the pro-B cell to produce $\mu \mathrm{H}$ chains, most of which are retained in the endoplasmic reticulum. The appearance of cytoplasmic $\mu \mathrm{H}$ chains defines the pre- $\mathrm{B}$ cell. 
Pre-B cells whose $\mu \mathrm{H}$ chains can associate VpreB, and $\lambda 14.1$ [ $\lambda 5$ ], which together form the surrogate light chain ( $\psi L C$ ), form a pre-B cell receptor. Its appearance turns off RAG1 and RAG2, preventing further $\mathrm{H}$ chain rearrangement (allelic exclusion). This is followed by four to six cycles of cell division (25). Late pre-B daughter cells reactivate RAG1 and RAG2 and begin to undergo $V_{1} \rightarrow J_{1}$ rearrangement. Successful production of a complete $\kappa$ or $\lambda$ light chain permits expression of conventional IgM on the cell surface (sIgM), which identifies the immature B cell. Immature B cells that have successfully produced an acceptable IgM B cell receptor extend transcription of the $\mathrm{H}$ chain locus to include the $\mathrm{C} \delta$ exons downstream of $\mathrm{C} \mu$. Alternative splicing permits co-production of $\operatorname{IgM}$ and IgD. These now newly mature $\operatorname{IgM}^{+} \operatorname{IgD}{ }^{+} \mathrm{B}$ cells enter the blood and migrate to the periphery where they form the majority of the B cell pool in the spleen and the other secondary lymphoid organs. The IgM and IgD on each of these cells share the same variable domains.

The life span of mature B cells expressing surface IgM and IgD appears entirely dependent on antigen selection. After leaving the bone marrow, unstimulated cells live only days or a few weeks. As originally postulated by Burnet's "clonal selection" theory, B cells are rescued from apoptosis by their response to a cognate antigen. The reaction to antigen leads to activation, which may then be followed by diversification. The nature of the activation process is critical. $T$ cell independent stimulation of $B$ cells induces differentiation into short-lived plasma cells with limited class switching. T-dependent stimulation adds additional layers of diversification, including somatic hypermutation of the variable domains, which permits affinity maturation, class switching to the entire array of classes available, and differentiation into the long-lived memory B cell pool or into the long-lived plasma cell population.

\section{Heavy chain $\mathrm{C}$ domain structure and function}

In general, the $\mathrm{C}$ domain of the $\mathrm{H}$ chain defines effector function, while the paired $\mathrm{V}$ domains of the antibody confer antigenic specificity. The $\mathrm{H}$ chain constant domain is generally defined as $\mathrm{CH} 1-\mathrm{CH} 2-\mathrm{CH} 3$ (IgG, IgA, IgD) with an additional domain (CH4) for $\mathrm{IgM}$ and $\mathrm{IgE}$. As described above, the $\mathrm{CH} 1$ domain is located within the $\mathrm{F}(\mathrm{ab})$ region whereas the remaining $\mathrm{CH}$ domains $(\mathrm{CH} 2-\mathrm{CH} 3$ or $\mathrm{CH} 2-\mathrm{CH} 4)$ comprise the $\mathrm{Fc}$ fragment. This Fc fragment defines the isotype and subclass of the immunoglobulin. Despite amino acid differences between the isotypes and subclasses, each $\mathrm{CH}$ region folds into a fairly constant structure consisting of a three strand-four strand beta sheet pinned together by an intrachain disulfide bond. The $\mathrm{Fc}$ fragment mediates effector function by binding to the $\mathrm{Fc}$ receptor on effector cells or activating other immune mediators such as complement.(26) For this reason, changes in the $\mathrm{Fc}$ region can significantly impact on the end result of an antibody-antigen interaction. The Fc region can also affect the affinity or kinetics of binding of the antibody by the Fv region, and thus influence antigen recognition or binding.(27)

\section{Role of glycosylation}

Immunoglobulins are glycoproteins and the glycans associated especially with the Fc domain of immunoglobulins have been shown to affect antibody function. The extent of glycosylation varies by isotype (Figure 6).(28) For IgG molecules, there is an N-linked glycosylation site located at Asn297 on each of the two $\mathrm{CH} 2$ domains. The core of this complex biantennary type of sugar is a heptasaccharide consisting of $\mathrm{N}$-acetylglucosamine and mannose. Variation in glycosylation is seen between $\operatorname{IgG}$ molecules as well as within the two sites on the same molecule due to differences in terminal sialic acid, galactose, Nacetylglucosamine and fucosylation of the core. These differences can lead to as many as 32 possible glycosylation patterns. The glycans at this site interact with a hydrophobic pocket on the Fc domain that stabilizes the immunoglobulin structure. $(29,30)$. At a similar site in $\mathrm{CH} 2$ of IgD, Asn354, mutations that prevent glycosylation are associated with the loss of 
IgD production, suggesting that glycans in $\mathrm{CH} 2$ can be essential for immunoglobulin stability.

Glycans on immunoglobulins profoundly influence binding to $\mathrm{Fc}$ receptors on effector cells as well as immune mediators. When IgG sequences are mutated such that glycosylation is eliminated, there is reduced or no binding of the aglycosylated IgG to Fc $\gamma \mathrm{R}$. This led to the suggestion that the N-glycan at Asn297 was critical for the engagement of IgG with Fc $\gamma$ R. This is in contrast to engagement between IgA and IgE and FcaR and FceR, respectively, where it had been shown that glycans were not required for interaction. Subsequently, it was shown that point mutations could be introduced to the $\mathrm{CH}$ domains that would permit binding to $\mathrm{Fc} \gamma \mathrm{R}$ in the absence of glycosylation.(31) However, the observation that the Asn297 site is conserved across evolution and that IgG is subjected to post-translational modifications at this site suggests that glycosylation at this position makes a significant contribution to antibody function in vivo.

A key effector function for IgG antibodies is antibody-dependent cellular cytotoxicity (ADCC) in which antibody coated antigens activate effector cells, such as NK cells or monocytes, to destroy the antibody coated target by binding of the complex to the Fc $\gamma \mathrm{R}$. The ADCC activity was shown to be significantly dependent on the glycan composition of the IgG and furthermore, the net result of binding to activating and inhibitory Fc $\gamma$ R. A number of engineered cell lines as well as glycosidase inhibitors are available to direct the sugar composition of glycans on an immunoglobulin. Through these studies, it was demonstrated that ADCC activity increases following a reduction in the fucose content of an antibody. $(32,33)$

Complement dependent cytotoxicity (CDC) is another effector function of $\operatorname{IgG}$ that is dependent on the binding of $\mathrm{Clq}$ to the $\mathrm{Fc}$ domain. Glycosylation also plays a role in CDC, requiring the presence of a complex structure containing at least two $\mathrm{N}$-acetylglucosamines with multiple galactoses and sialic acids.

There are also experiments of nature in which aberrantly glycosylated immunoglobulins are associated with detrimental effects. For example, higher than normal levels of IgG lacking sialic acid or galactose are found in patients suffering from a number of autoimmune diseases, rheumatoid arthritis in particular. $\mathrm{N}$-glycans terminate with $\mathrm{N}$-acetylglucosamine which may activate the complement cascade through mannose binding lectin (MBL) and create an inflammatory state.(34) Removal of the majority of the secondary glycan structure using Endo-S (one N-acetylglucosamine and/or a terminal fucose remains with the core sugar) has been shown to reduce the pathogenesis and pro-inflammatory properties of autoantibodies in murine models (35). This is not limited to $\operatorname{IgG}$ as a reduction in terminal galactose on IgA has been associated with decreased clearance of IgA from the circulation, with the subsequent development of nephropathy.

IVIG can be used in selected circumstances to ameliorate inflammatory diseases. The antiinflammatory activity of IVIG has shown to be associated with sialic acid in a 2,6 linkage to a terminal galactose on IgG. Recently, a receptor specific to this sialyated $\mathrm{Fc}$ has been identified on myeloid cells.(36) Engagement of this receptor with sialyated IgG may upregulate inhibitory Fc $\gamma \mathrm{R}$ to reduce inflammation by means of IgG/activating Fc $\gamma \mathrm{R}$ engagement.

Immunoglobulin glycosylation may also alter other antibody functions. For example,, it has been shown that an anti-HIV antibody that fails to neutralize acquires neutralization activity when expressed in a cell line that results in post-translational modification of an antibody with a marked elevation in sialic acid, fucose and $\mathrm{N}$-acetylglucosamine.(37) It is 
hypothesized that it is the glycan interactions between the antibody and virus interfere with the normal infection process.

O-linked glycans also play a pivotal role in the immune response. There are several potential O-linked sites in the hinge region of $\operatorname{IgD}$ and $\operatorname{IgA}$ antibodies which serve to protect the hinge from proteases and/or bind bacteria. Understanding the impact of differential glycosylation on immunoglobulin function is contributing to the design of more effective immunotherapies through either engineered passive immunotherapy 4 or in vivo treatment with glycan modifiers.(38)

\section{Heavy Chain Isotypes}

Early in B cell development, productively rearranged variable domains (VH and VL) are expressed in association with the $\mu$ heavy chain to produce $\operatorname{IgM}$, and then IgD by means of alternative splicing. Later during development, and in response to antigenic stimulation and cytokine regulation, these variable domains may associate with the other isotypes (IgG, IgA and $\operatorname{IgE}$ ) in a controlled process. That is, isotype switching does not occur merely by chance. The $\mathrm{CH}$ genes for each isotype are aligned in the same transcriptional orientation, on human chromosome 14. Isotypes differ in a number of properties including size, complement fixation, FcR binding and the isotype response to antigen. The choice of isotype is dependent upon the antigen itself and the signaling pathways that are activated, as well as the local microenvironment (summarized in Table 1).

$\lg$ M-IgM is the first immunoglobulin expressed during B cell development. Naïve B cells express monomeric IgM on their surface and associate with CD79a and CD79b, polypeptide chains that participate in IgM cell signaling. Upon maturation and antigenic stimulation, multimeric (usually pentameric, rarely hexameric) $\operatorname{IgM}$, in which single IgM units link to each other by disulfide bonds in the $\mathrm{CH} 4$ region, is secreted. The pentamer also contains a polypeptide chain, the J-chain, which is bound to two of the monomers by means of a disulfide bond. The J-chain facilitates secretion at mucosal surfaces (see below). Generally, while monomeric IgM molecules have low affinity due to their immaturity; high avidity can be attained by means of multimeric interactions between the pentameric secreted antibody and the antigen, especially if that antigen contains multiple repeating epitopes itself. IgM functions by opsonizing (coating) antigen for destruction and fixing complement. The pentameric nature of the antibody renders it very efficient in this process.

$\operatorname{IgM}$ antibodies are associated with a primary immune response and are frequently used to diagnose acute exposure to an immunogen or pathogen. Given that IgM is expressed early in B cell development, the $\mu$ heavy chain associates with VH and VL that have not undergone much somatic mutation in response to antigen. As a result, IgM antibodies tend to be more poly-reactive than other isotypes, which allows IgM-bearing B cells to respond quickly to a variety of antigens. These relatively low-affinity IgM antibodies are also called natural antibodies. Some of these natural antibodies not only participate as a first line of defense, but also play a role in immunoregulation.(39) Natural antibodies may react with autoantigens, but are rarely responsible for autoimmune disease or pathogenesis. Pathogenic autoantibodies tend to be drawn from the somatically mutated, high affinity $\operatorname{IgG}$ population.

$\lg \mathrm{D}$-Circulating $\operatorname{IgD}$ is found at very low levels in the serum with a short serum half-life which may be attributed to sensitivity of the molecule, with the hinge region in particular, to proteolysis. The function of circulating IgD is unclear, as it is not known to participate in the major antibody effector mechanisms. Circulating IgD can react with specific bacterial proteins, such as the IgD binding protein of Moraxella catarrhalis, independent of the 
variable regions of the antibody.(40) The binding of these bacterial proteins to the constant region of $\mathrm{IgD}$ results in $\mathrm{B}$ cell stimulation and activation.

While the membrane-bound form of $\operatorname{IgD}$ that has been more extensively studied; even here its function remains poorly understood. Similar to $\operatorname{IgM}$, membrane bound $\operatorname{IgD}$ is associated with CD79a and CD79b for signaling. IgD is expressed on the membranes of B cells when they leave the bone marrow and populate secondary lymphoid organs. Most $\operatorname{IgD}^{+} \mathrm{B}$ cells also co-express IgM and both participate in B cell receptor signaling through CD79a and $\mathrm{CD} 79 \mathrm{~b}$. IgD can replace $\operatorname{IgM}$ and vice versa on $\operatorname{IgD}^{+} \operatorname{IgM}{ }^{+} \mathrm{B}$ cells. It has been proposed that membrane bound IgD regulates $\mathrm{B}$ cell fate at specific developmental stages through changes in activation status.(41)

$\lg$ - $-\operatorname{IgG}$ is the predominant isotype found in the body. It has the longest serum half-life of all immunoglobulin isotypes. It is also the most extensively studied class of immunoglobulins. Based on structural, antigenic and functional differences in the constant region of the heavy chain, and $\mathrm{CH} 1$ and $\mathrm{CH} 3$ in particular, four $\operatorname{IgG}$ subclasses (IgG1, $\operatorname{IgG} 2$, $\mathrm{IgG} 3$ and $\mathrm{IgG} 4$ ) were identified. These IgG subclasses were numbered in reference to the rank order (IgG1>IgG2>IgG3>IgG4) of the serum levels of these antibodies in the blood of normal, healthy individuals living in an affluent western European environment. The differences in the $\mathrm{CH}$ domains affect antibody flexibility and functional affinity, some of which facilitate cooperative interactions with multivalent antigens. The mobility or flexibility of the $\mathrm{F}(\mathrm{ab})$ and the $\mathrm{Fv}$ portions of the antibody are primarily controlled by the $\mathrm{CH} 1$ domain and hinge region. The IgG subclasses exhibit different functional activities. Activation of the complement cascade is an important means of clearance of opsonized pathogens. While IgG4 is the only subclass that fails to fix complement; affinity for C1q, which is the first component of the complement pathway and which binds to the $\mathrm{CH} 2$ domain of IgG, differs between members of the other three IgG subclasses, with $\operatorname{IgG} 3>\operatorname{IgG} 1>\operatorname{IgG} 2$. There are also defined differences in the affinity to the three classes of Fc $\gamma$ R (I, II and III). IgG1 and IgG3 bind to all three Fc $\gamma$ R classes. IgG4 binds only Fc $\gamma$ RII and III, albeit significantly weaker than the binding of IgG1. And IgG2 binds only to Fc $\gamma$ RII.

There are also similarities within the subclasses such as transplacental transport and participation in the secondary immune response. Within the secondary antibody response, there is skewing in the predominant subclass that is induced. For example, IgG1 and IgG3 antibodies are generally induced in response to protein antigens whereas IgG2 and IgG4 are associated with polysaccharide antigens. The response to a given antigen can also result in a skewed $\operatorname{IgG}$ subclass response and this is frequently as source of investigation as to correlates of protection or for the design of vaccines.

Specific subclasses may be associated with individual disease processes. For example, in pemphigus vulgaris, a mucocutaneous blistering disease, IgG4 antibodies to desmoglein 3 are pathogenic $(42,43)$ whereas first degree relatives with $\operatorname{IgG1}$ autoantibodies to the same protein show no evidence of the disease.

IgG antibodies also contribute directly to an immune response including neutralization of toxins and viruses. Here again, $\operatorname{IgG}$ subclass impacts on the outcome of this interaction. In HIV, it has been shown that IgG3 antibodies may be more effective at neutralizing virus than IgG1 antibodies, presumably through an increase in antibody flexibility improving antibody access or inducing changes in the oligomer structure of the virus. $(44,45)$

$\lg \mathrm{A}$ - $\operatorname{Ig} \mathrm{A}$ serum levels tend to be higher than $\operatorname{IgM}$, but considerably lower levels than $\operatorname{IgG}$. Conversely, $\operatorname{IgA}$ levels are much higher than $\mathrm{IgG}$ at mucosal surfaces and in secretions, 
including the saliva and breast milk (46). In particular, IgA can contribute up to $50 \%$ of the protein in colostrum, the 'first milk' given to the neonate by the mother. While generally a monomer in the serum, $\operatorname{IgA}$ at the mucosa, termed secretory $\operatorname{Ig} \mathrm{A}(\operatorname{sg} \mathrm{A})$, is a dimer (sometimes trimer and tetramer) associated with a J-chain and another polypeptide chain, the secretory component (discussed below). Similar to IgM, the CH3 domains of IgA have short tailpieces to which the J-chain binds via disulfide bonds whereas the secretory component is disulfide bonded to one of the $\mathrm{CH} 2$ domains of the dimer. There are two subclasses of $\operatorname{IgA}$, $\operatorname{IgA} 1$ and $\operatorname{IgA} 2$, whose structures differ mainly in their hinge regions. IgA1 has a longer hinge region with a duplicated stretch of amino acids that is lacking in IgA2. This elongated hinge region increases the sensitivity of $\operatorname{IgA} 1$ to bacterial proteases in spite of partial protection by glycans. Such increased protection against protease digestion may explain why IgA2 predominates in the many mucosal secretions, such as the genital tract, whereas more than $90 \%$ of serum $\operatorname{IgA}$ is in the form of $\operatorname{IgA} 1$.

IgA is critical at protecting mucosal surfaces from toxins, virus and bacteria by direct neutralization or by prevention of binding to the mucosal surface. Intracellular IgA may also be important in preventing bacterial or viral infection and/or pathogenesis. The polymeric nature of secretory $\operatorname{IgA}$ may be particularly important. For example, polymeric $\operatorname{IgA}$ is more effective than monomeric IgA at preventing Clostridium difficile toxin A damage to epithelial cells.(47) While complement fixation by IgA does not appear to be a major effector mechanism at the mucosal surface, the IgA receptor is expressed on neutrophils which may be activated to mediate ADCC locally. As described above, specific bacteria may be trapped by the glycans on IgA. Finally, it has been proposed that sIgA may also act as a potentiator of the immune response in intestinal tissue by uptake of antigen to dendritic cells.(48)

IgE-Though it is present at the lowest serum concentration with the shortest half-life, IgE is a very potent immunoglobulin. It is associated with hypersensitivity and allergic reactions as well as the response to parasitic worm infections. IgE binds with extremely high affinity to the FceRI which is expressed on mast cells, basophils, Langerhans cells and eosinophils. Circulating IgE upregulates FceR expression on these cells. The combination of strong binding and upregulation of FceR expression contributes to the remarkable potency of this immunoglobulin.

Recently, there has been the development of anti-IgE antibodies as therapy for allergy and asthma.(49) Antibodies are designed to target free IgE as well as B cells with membrane bound IgE but not IgE bound to FceR as the latter would stimulate degranulation and the release of inflammatory mediators. IgE has a much lower affinity for FceRII or CD23, which is expressed both on the same cells as FceRI as well as B cells, NK cells and platelets.

\section{Higher Order Structures}

The $\mathbf{J}$ chain-The $\mathbf{J}$-chain is a relatively conserved, $15-16 \mathrm{kd}$ polypeptide (137 amino acids) incorporated into polymeric IgA or IgM in the antibody producing cell during the secretory pathway. There are six cysteine residues for intrachain disulfide bonds plus the two cysteines for attachment to IgA or IgM tailpiece. There is a single N-linked glycan which contributes approximately $8 \%$ of the mass to the molecule. This glycan is critical to association with monomeric IgA. While the J-chain is produced by B cells, it is not necessarily produced by all $\mathrm{B}$ cells. It appears J-chain expression may be restricted to those areas, such as the lamina propria, in which mucosal antibody is important as opposed to B cells in the distal bone marrow. Free J-chain is not found outside the cell and is only found as part of the pIg complex. It has been shown that J-chain is essential for polymerization and 
secretion of IgA. In contrast, pentameric IgM requires J-chain for secretion (but not formation), and hexameric IgM does not require J-chain at all.

Dimers, pentamers and hexamers-Polymeric Ig is generally more effective than monomeric Ig in terms of binding to FcR on the cell surface. As described above, IgA and IgM molecules have the capacity to be naturally expressed as multimeric antibodies. Both Ig have a short tailpiece ( 18 amino acids) in the $\mathrm{CH} 3$ domain with a penultimate cysteine residue to which the J-chain forms a disulfide bond with one of the monomers with the other forming a tailpiece to tailpiece disulfide bond. Typically dimeric structures are formed for $\operatorname{Ig} \mathrm{A}$ and pentameric structures for $\operatorname{IgM}$.

\section{Fc Receptors}

\section{FcyR}

Fc receptors for immunoglobulin link the humoral immune compartment to the cellular immune compartment. The net result of binding of Ig to receptor is a function of the receptor, the cell on which it is expressed, and on any ancillary signals. Tight regulation of binding to FcR is necessary to maintain a healthy immune system.

The most extensively studied $\mathrm{Fc}$ receptors the IgG binding receptors, termed $\mathrm{Fc} \gamma \mathrm{R}$. In humans, three classes of Fc $\gamma \mathrm{R}$ have been identified: I, II and III. Fc $\gamma$ RII and Fc $\gamma$ RIII each have two isoforms, $\mathrm{A}$ and $\mathrm{B}$. These Fc $\gamma \mathrm{R}$ are expressed, to varying degrees, on many hematopoietic cells, as well other cells such as endothelial cells. T cells have proven to be a stark exception. The Fc $\gamma \mathrm{R}$ differ in their binding affinity to IgG, with Fc $\gamma$ RI showing the highest affinity whereas Fc $\gamma$ RII and Fc $\gamma$ RIII bind with lower affinity. For that reason, only $\mathrm{Fc} \gamma \mathrm{RI}$ binds monomeric IgG while the other two receptors bind aggregated IgG or immune complexes. Of note, $\mathrm{Fc} \gamma \mathrm{RI}$ has three extracellular domains whereas Fc $\gamma$ RII and Fc $\gamma$ RIII have only two extracellular domains.

As described above, there are differences in binding of IgG subclasses to Fc $\gamma \mathrm{R}$. There are also differences in the signaling pathway that is associated with each Fc $\gamma \mathrm{R}$. Fc $\gamma \mathrm{RI}$, Fc $\gamma$ RIIA, and Fc $\gamma$ RIIIA all transduce an activating signal when IgG binds. However, Fc $\gamma$ RIIB transmits an inhibitory signal and no signal is associated with binding to Fc $\gamma$ RIIIB. While the other Fc $\gamma$ R are typical transmembrane proteins, Fc $\gamma$ RIIIB lacks this feature and instead is attached by glyco-phosphatidylinosital tail. The end result of the interaction of antibody and antigen with Fc $\gamma \mathrm{R}$ tends to be a balancing act between inhibitory and stimulatory activities, and a complex function of the IgG subclass, the particular Fc $\gamma R$ bound, and the cells expressing the Fc $\gamma$ R.(50)

\section{FcyR}

There is another $\mathrm{Fc} \gamma \mathrm{R}$, the neonatal $\mathrm{Fc}$ receptor $(\mathrm{FcRn})$ which was originally shown to mediate the transcytosis of maternal IgG to the neonate. Subsequently, it was determined that the FcRn is also responsible for the regulation of serum IgG levels. IgG binds to FcRn in the acidic environment of the endosomes, which protects it from destruction by lysosomes. The IgG is recycled to the surface and released into circulation by the $\mathrm{pH}$ change. The FcRn is saturable and once $\mathrm{IgG}$ levels exceed a threshold, it is degraded by the lysosomes. Whereas the $\mathrm{CH} 3$ domain of $\mathrm{IgG} \mathrm{Fc}$ binds to $\mathrm{Fc} \gamma \mathrm{R}$, it is the $\mathrm{CH} 2-\mathrm{CH} 3$ region that binds to FcRn. Binding is thus independent of the sugar moiety which is attached to the $\mathrm{CH} 2$ domain. It should also be noted that binding toFcRn is strictly pH dependent whereas this is not the case with Fc $\gamma$ R. Mutagenesis studies have demonstrated that mutations in the $\mathrm{Fc}$ region can increase or decrease interactions with FcRn. For example, mutations at positions 250 and 428 of IgG1 resulted in an increase in serum half-life for single mutant 
M428L and the double mutant T250Q/M428L.(51) Others have shown that a single mutation of human IgG1, N434A and a triple mutant T307A/E380A/N434A also show an enhanced half-life when tested in human FcRn transgenic mice.(52) That affinity for FcRn can be increased, resulting in increased immunoglobulin half-life, suggests that improved therapeutics may be designed to decrease dosing.

\section{FceR}

The Fc receptors for IgE are also relatively well studied, especially in terms of the development of therapeutic anti-IgE antibodies for the treatment of allergy and asthma as described above. It is the $\mathrm{CH} 3$ domain of IgE that binds to FceRI and CD23; however, there are distinct differences in binding. FceRI captures both $\mathrm{CH} 3$ domains of IgE due to the unique shape of the IgE molecule. On the other hand, CD23 consists of a trimer on the cell surface and two heads of this trimer must separately contact a $\mathrm{CH} 3$ domain of IgE for strong binding.

\section{FcaR}

The FcR for IgA, CD89, is expressed on myeloid cells including PMN, monocytes, and a population of dendritic cells. There are five exons including two extracellular domains, EC1 and EC2, each of which encodes a single Ig-like domain. IgA binds to membrane distal EC1 in contrast to the usual binding of $\operatorname{IgG}$ to the membrane proximal extracellular domain of Fc $\gamma$ R. Multiple splice variants have been demonstrated and whereas full-length CD89 binds polymeric IgA with higher affinity than serum IgA, there is no difference in binding to truncated CD89. Signaling through the FcaR is accomplished through the FcR $\gamma$-chain which contains an ITAM (immunoreceptor tyrosine-based activation motif) signaling motif. Not all FcaR associate with $\gamma$-chain resulting in " $\gamma$-less" FcR which endocytoses bound $\operatorname{IgA}$ to early endosomes and then recycles IgA back to the cell surface. Cross-linking of FcaR, with an associated $\gamma$-chain, results in the activation of a number of signaling molecules in the lipid rafts, calcium release and induction of NADPH oxidase activity. Outside of endocytosis, the biological and cellular functions of PMN following FcaR stimulation are dependent upon tyrosine kinase activity of the associated $\gamma$-chain. Crosslinking of FcaR has also been shown to induce effector functions such as phagocytosis and ADCC.

\section{FcסR}

The $\mathrm{FcR}$ for $\mathrm{IgD}$ is less well understood. A receptor for $\mathrm{IgD}$ has been reported to be present on human CD4 and CD8 T cells. Its expression is upregulated by mitogenic stimulation of the $\mathrm{T}$ cells. Binding of $\mathrm{IgD}$ to this putative $\mathrm{Fc} \delta \mathrm{R}$ is mediated by glycans on the $\mathrm{IgD}$ surface and may not necessarily be a function of a defined Fc $\delta R$. Binding of IgD to receptors with putative $\mathrm{Fc} \delta \mathrm{R}$ activity on $\mathrm{T}$ cells has been proposed to serve as a "bridge" for stimulation of IgD expressing $\mathrm{B}$ cells or as antigen presentation by the $\mathrm{B}$ cells to the $\mathrm{T}$ cells, but this remains controversial.

\section{Immunoglobulin transport}

The transport of polymeric $\mathrm{Ig}(\mathrm{pIg})$ into mucosal secretions is a function of the polymeric Ig receptor (pIgR). This receptor is found on the basolateral surface of epithelial cells lining the mucosal surface. Membrane bound pIgR is consists of five Ig-like domains (extracellular portion) with a transmembrane and cytoplasmic domain. Polymeric IgA (with the J-chain) binds to the pIgR on the epithelial cell. It is then internalized and transcytosed to the apical cell membrane. The extracellular portion of the $\mathrm{pIgR}$ is cleaved to form the secretory component (SC) and covalently associates with the polymeric IgA (pIgA). The complex of pIgA with secretory component forms secretory $\operatorname{IgA}(\operatorname{sIgA})$. The SC forms a disulfide link 
with Cys 311 in $\mathrm{Ca} 2$ of one of the monomers of the pIgA. While the secretory component is not physically associated with the $\mathrm{J}$ chain of the $\mathrm{pIgA}$, the $\mathrm{J}$ chain is required for secretory component to associate with $\mathrm{pIgA}$. SC is not covalently linked to pentameric IgM but rather associates non-covalently with pentameric IgM due to excess free SC.

Extensive analysis of the glycosylation patterns of the components of secretory IgA has predicted a model in which most of the molecule is covered in glycans with the exception of the $F(a b)$ or antigen binding sites. In this manner, secretory IgA participates in both the adaptive (antigen binding) and innate (adhesion due to glycans) arms of the immune system. Although the SC does not have a direct role in the biological activity of sIgA, it does confer some protection from proteolytic cleavage after secretion and anchors the sIgA to mucous lining the epithelium. Moreover, as a result of covalent binding of SC to $\operatorname{PIgA}$, $\operatorname{SIgA}$ is the most stable immunoglobulin in secretions.

\section{Acknowledgments}

The authors would like to thank Ms. Elena M. Schroeder for her help in creating the figures for this manuscript.

\section{Abbreviations (used in text)}

$\begin{array}{ll}\text { ADCC } & \text { antibody-dependent cellular cytotoxicity } \\ \text { AID } & \text { Activation induced cytosine deaminase } \\ \text { CDC } & \text { complement dependent cytotoxicity } \\ \text { CSR } & \text { class switch recombination } \\ \text { C } & \text { constant } \\ \text { H } & \text { heavy } \\ \text { Ig } & \text { immunoglobulin } \\ \text { L } & \text { light } \\ \text { pIgA } & \text { polymeric IgA } \\ \text { RSS } & \text { recombination signal sequence } \\ \text { SC } & \text { secretory component } \\ \text { SCID } & \text { severe combined immune deficiency } \\ \text { SHM } & \text { somatic hypermutation } \\ \text { TDT } & \text { terminal deoxynucleotidyl transferase } \\ \text { V } & \text { variable }\end{array}$

\section{References}

1. Williams AF, Barclay AN. The immunoglobulin superfamily--domains for cell surface recognition. Annu. Rev. Immunol. 1988; 6:381-405. [PubMed: 3289571]

2. Harpaz Y, Chothia C. Many of the immunoglobulin superfamily domains in cell adhesion molecules and surface receptors belong to a new structural set which is close to that containing variable domains. J. Mol. Biol. 1994; 238:528-539. [PubMed: 8176743]

3. Torres, RM.; Imboden, J.; Schroeder, HW, Jr.. Antigen receptor genes, gene products, and coreceptors. In: Rich, RR.; Fleisher, TA.; Shearer, WT.; Schroeder, HW., Jr.; Frew, AJ.; Weyand, CM., editors. Clinical Immunology: Principles and Practice. 3 ed.. London: Mosby Elsevier; 2008. p. 53-77. 
4. Smith KA, Nelson PN, Warren P, Astley SJ, Murray PG, Greenman J. Demystified...recombinant antibodies. J Clin Pathol. 2004; 57:912-917. PMC1770420. [PubMed: 15333649]

5. Hamers-Casterman C, Atarhouch T, Muyldermans S, Robinson G, Hamers C, Songa EB, Bendahman N, Hamers R. Naturally occurring antibodies devoid of light chains. Nature. 1993; 363:446-448. [PubMed: 8502296]

6. Roux KH, Greenberg AS, Greene L, Strelets L, Avila D, McKinney EC, Flajnik MF. Structural analysis of the nurse shark (new) antigen receptor (NAR): molecular convergence of NAR and unusual mammalian immunoglobulins. Proc. Nat. Acad. Sci. ,U. S. A. 1998; 95:11804-11809.

7. Vincke C, Loris R, Saerens D, Martinez-Rodriguez S, Muyldermans S, Conrath K. General strategy to humanize a camelid single-domain antibody and identification of a universal humanized nanobody scaffold. Journal of Biological Chemistry. 2009; 284:3273-3284. [PubMed: 19010777]

8. Jazwinska EC, Dunckley H, Propert DN, Gatenby PA, Serjeantson SW. GM typing by immunoglobulin heavy chain gene RFLP analysis. Am. J. Hum. Genet. 1988; 43:175-181. [PubMed: 2899972]

9. Leder P. The genetics of antibody diversity. Sci. Am. 1982; 246(5):102-115. [PubMed: 6177035]

10. Tonegawa S. Somatic generation of antibody diversity. Nature. 1983; 302:575-581. [PubMed: 6300689]

11. Dudley DD, Chaudhuri J, Bassing CH, Alt FW. Mechanism and control of V(D)J recombination versus class switch recombination: similarities and differences. Adv. Immunol. 2005; 86:43-112. [PubMed: 15705419]

12. Zachau, HG. The human immunoglobulin kappa genes. In: Honjo, T.; Alt, FW.; Rabbitts, PH., editors. Immunoglobulin genes. 2 ed.. London: Academic Press; 1995. p. 173

13. Brodeur PH, Riblet RJ. The immunoglobulin heavy chain variable region (IgH-V) locus in the mouse. I. One hundred Igh-V genes comprise seven families of homologous genes. Eur. J. Immunol. 1984; 14:922-930. [PubMed: 6092095]

14. Kirkham PM, Schroeder HW Jr. Antibody structure and the evolution of immunoglobulin V gene segments. Semin. Immunol. 1994; 6:347-360. [PubMed: 7654992]

15. Lee SK, Bridges SL Jr. Koopman WJ, Schroeder HW Jr. The immunoglobulin kappa light chain repertoire expressed in the synovium of a patient with rheumatoid arthritis. Arthr Rheum. 1992; 35:905-913. [PubMed: 1642656]

16. Kawasaki K, Minoshima S, Nakato E, Shibuya K, Shintani A, Schmeits JL, Shimizu N. Onemegabase sequence analysis of the human immunoglobulin lambda gene locus. PCR Methods \& Applications. 1997; 7:250-261.

17. Bankovich AJ, Raunser S, Juo ZS, Walz T, Davis MM, Garcia KC. Structural insight into pre-B cell receptor function. Science. 2007; 316:291-294. [PubMed: 17431183]

18. Matsuda F, Ishii K, Bourvagnet P, Kuma K, Hayashida H, Miyata T, Honjo T. The complete nucleotide sequence of the human immunoglobulin heavy chain variable region locus. J. Exp. Med. 1998; 188:2151-2162. [PubMed: 9841928]

19. Corbett SJ, Tomlinson IM, Sonnhammer EL, Buck D, Winter G. Sequence of the human immunoglobulin diversity (D) segment locus: a systematic analysis provides no evidence for the use of DIR segments, inverted D segments, "minor" D segments or D-D recombination. J. Mol. Biol. 1997; 270:587-597. [PubMed: 9245589]

20. Honjo T. Immunoglobulin genes. Annu. Rev. Immunol. 1983; 1:499-528. [PubMed: 6443559]

21. Dorner T, Foster SJ, Farner NL, Lipsky PE. Somatic hypermutation of human immunoglobulin heavy chain genes: targeting of RGYW motifs on both DNA strands. Eur. J. Immunol. 1998; 28:3384-3396. [PubMed: 9808208]

22. Rada C, Ehrenstein MR, Neuberger MS, Milstein C. Hot spot focusing of somatic hypermutation in MSH2-deficient mice suggests two stages of mutational targeting. Immunity. 1998; 9:135-141. [PubMed: 9697843]

23. Neuberger MS. Antibody diversification by somatic mutation: from Burnet onwards. Immunology and Cell Biology. 2008; 86:124-132. [PubMed: 18180793]

24. Muramatsu M, Nagaoka H, Shinkura R, Begum NA, Honjo T. Discovery of activation-induced cytidine deaminase, the engraver of antibody memory. Adv. Immunol. 2007; 94:1-36. [PubMed: 17560270] 
25. Matthias P, Rolink AG. Transcriptional networks in developing and mature B cells. Nature Reviews Immunology. 2005; 5:497-508.

26. Normansell DE. Human immunoglobulin subclasses. Diagn Clin Immunol. 1987; 5:115-128. [PubMed: 3319279]

27. Torres M, Casadevall A. The immunoglobulin constant region contributes to affinity and specificity. Trends Immunol. 2008; 29:91-97. [PubMed: 18191616]

28. Arnold JN, Wormald MR, Sim RB, Rudd PM, Dwek RA. The impact of glycosylation on the biological function and structure of human immunoglobulins. Annu. Rev. Immunol. 2007; 25:2150. [PubMed: 17029568]

29. Liu H, Bulseco G-G, Sun J. Effect of posttranslational modifications on the thermal stability of a recombinant monoclonal antibody. Immunology Letters. 2006; 106:144-153. [PubMed: 16831470]

30. Siberil S, de Romeuf C, Bihoreau N, Fernandez N, Meterreau JL, Regenman A, Nony E, Gaucher C, Glacet A, Jorieux S, Klein P, Hogarth MP, Fridman WH, Bourel D, Beliard R, Teillaud JL. Selection of a human anti-RhD monoclonal antibody for therapeutic use: impact of IgG glycosylation on activating and inhibitory Fc gamma R functions. Clin. Immunol. 2006; 118:170179. [PubMed: 16332457]

31. Sazinsky SL, Ott RG, Silver NW, Tidor B, Ravetch JV, Wittrup KD. Aglycosylated immunoglobulin G1 variants productively engage activating Fc receptors. Proc. Nat. Acad. Sci. U. S. A. 2008; 105:20167-20172.

32. Kanda Y, Yamada T, Mori K, Okazaki A, Inoue M, Kitajima-Miyama K, Kuni-Kamochi R, Nakano R, Yano K, Kakita S, Shitara K, Satoh M. Comparison of biological activity among nonfucosylated therapeutic IgG1 antibodies with three different N-linked Fc oligosaccharides: the high mannose, hybrid and complex types. Glycobiology. 2006; 17:104-118. [PubMed: 17012310]

33. Natsume A, Wakitani M, Yamane-Ohnuki N, Shoji-Hosaka E, Niwa R, Uchida K, Satoh M, Shitara K. Fucose removal from complex-type oligosaccharide enhances the antibody-dependent cellular cytotoxicity of single-gene-encoded antibody comprising a single-chain antibody linked the antibody constant region. J. Immunol. Meth. 2005; 306:93-103.

34. Arnold JN, Dwek RA, Rudd PM, Sim RB. Mannan binding lectin and its interaction with immunoglobulins in health and in disease. Immunology Letters. 2006; 106:103-110. [PubMed: 16814399]

35. Albert H, Collin M, Dudziak D, Ravetch JV, Nimmerjahn F. In vivo enzymatic modulation of IgG glycosylation inhibits autoimmune disease in an IgG subclass-dependent manner. Proc. Nat. Acad. Sci. ,U. S. A. 2009; 105:15005-15009.

36. Anthony RM, Wermeling F, Karlsson MC, Ravetch JV. Identification of a receptor required for the anti-inflammatory activity of IVIG. Proc. Nat. Acad. Sci. ,U. S. A. 2008; 105:19571-19578.

37. Miranda LR, Duval M, Doherty H, Seaman MS, Posner MR, Cavacini LA. The neutralization properties of a HIV-specific antibody are markedly altered by glycosylation events outside the antigen-binding domain. J. Immunol. 2007; 178:7132-7138. [PubMed: 17513762]

38. Collin M, Shannon O, Bjorck L. IgG glycan hydrolysis by a bacterial enzyme as a therapy against autoimmune conditions. Proc. Nat. Acad. Sci. ,U. S. A. 2008; 105:4265-4270.

39. Boes M. Role of natural and immune IgM antibodies in immune responses. Mol. Immunol. 2000; 37:1141-1149. [PubMed: 11451419]

40. Riesbeck K, Nordstrom T. Structure and immunological action of the human pathogen Moraxella catarrhalis IgD-binding protein. Critical Reviews in Immunology. 2006; 26:353-376. [PubMed: 17073558]

41. Geisberger R, Lamers M, Achatz G. The riddle of the dual expression of IgM and IgD. Immunol. 2006; 118:429-437.

42. Parlowsky T, Welzel J, Amagai M, Zillikens D, Wygold T. Neonatal pemphigus vulgaris: IgG4 autoantibodies to desmoglein 3 induce skin blisters in newborns. Journal of the American Academy of Dermatology. 2003; 48:623-625. [PubMed: 12664033]

43. Yeh SW, Cavacini LA, Bhol KC, Lin MS, Kumar M, Duval M, Posner MR, Ahmed AR. Pathogenic human monoclonal antibody against desmoglein 3. J. Immunol. 2006; 120:68-75. 
44. Cavacini LA, Kuhrt D, Duval M, Mayer K, Posner M. Binding and neutralization activity of IgG1 and IgG3 from serum of HIV infected individuals. AIDS Research \& Human Retroviruses. 2003; 19:785-792. [PubMed: 14585209]

45. Scharf O, Golding H, King LR, Eller N, Frazier D, Golding B, Scott DE. Immunoglobin G3 from polyclonal human immunodeficiency virus (HIV) immune globulin is more potent than other subclasses in neutralizing HIV type 1. J. Virol. 2001; 75:6558-6565. [PubMed: 11413323]

46. Woof JM, Mestecky J. Mucosal immunoglobulins. Immunol Rev. 2005; 206:64-82. [PubMed: 16048542]

47. Stubbe H, Berdoz J, Kraehenbuhl JP, Corthesy B. Polymeric IgA is superior to monomeric IgA and $\mathrm{IgG}$ carrying the same variable domain in preventing Clostridium difficile toxin A damaging of T84 monolayers. J. Immunol. 2000; 164:1952-1960. [PubMed: 10657645]

48. Corthesy B. Roundtrip ticket for secretory IgA: role in mucosal homeostasis? J. Immunol. 2007; 178:27-32. [PubMed: 17182536]

49. Chang TW, Wu PC, Hsu CL, Hung AF. Anti-IgE antibodies for the treatment of IgE-mediated allergic diseases. Adv. Immunol. 2007; 93:63-119. [PubMed: 17383539]

50. Nimmerjahn F, Ravetch JV. FC-receptors are regulators of immunity. Adv. Immunol. 2007; 96:179-204. [PubMed: 17981207]

51. Hinton PR, Johlfs MG, Xiong JM, Hanestad K, Ong KC, Bullock C, Keller S, Tang MT, Tso JY, Vasquez M, Tsurushita N. Engineered human IgG antibodies with longer serum half-lives in primates. Journal of Biological Chemistry. 2004; 279:6213-6216. [PubMed: 14699147]

52. Petkova SB, Akilesh S, Sproule TJ, Christianson GJ, Al Khabbaz H, Brown AC, Presta LG, Meng YG, Roopenian DC. Enhanced half-life of genetically engineered human IgG1 antibodies in a humanized FcRn mouse model: potential application in humorally mediated autoimmune disease. Int. Immunol. 2006; 18:1759-1769. [PubMed: 17077181] 
Model of an immunoglobulin:

$\mathrm{H}$ = Heavy chain

$\mathrm{L} \quad=$ Light chain

$\mathrm{N}=$ Amino terminus

C $=$ Carboxy terminus

$\mathrm{s}-\mathrm{s} \quad=$ Disulfide bridge

$\mathrm{Gm}=$ Allotype (Genetic marker)
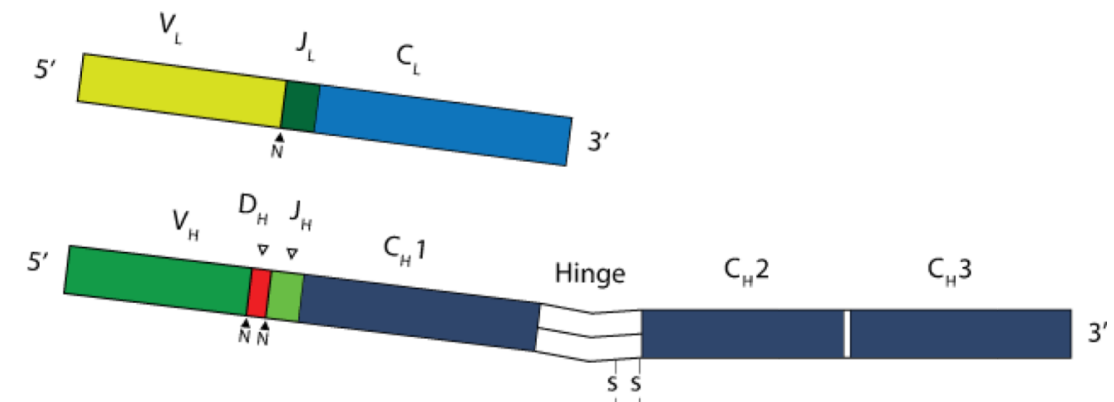

$H N$

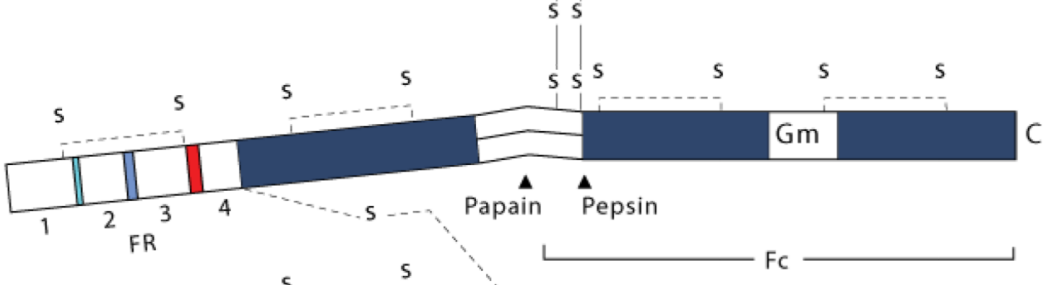

LN

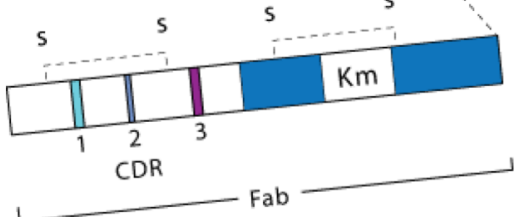

Figure 1. Two-dimensional model of an IgG molecule

The $\mathrm{H}$ and $\mathrm{L}$ chains at the top deconstruct the antibody at a nucleotide level. The chains at the bottom deconstruct the protein sequence. See text for further details. 


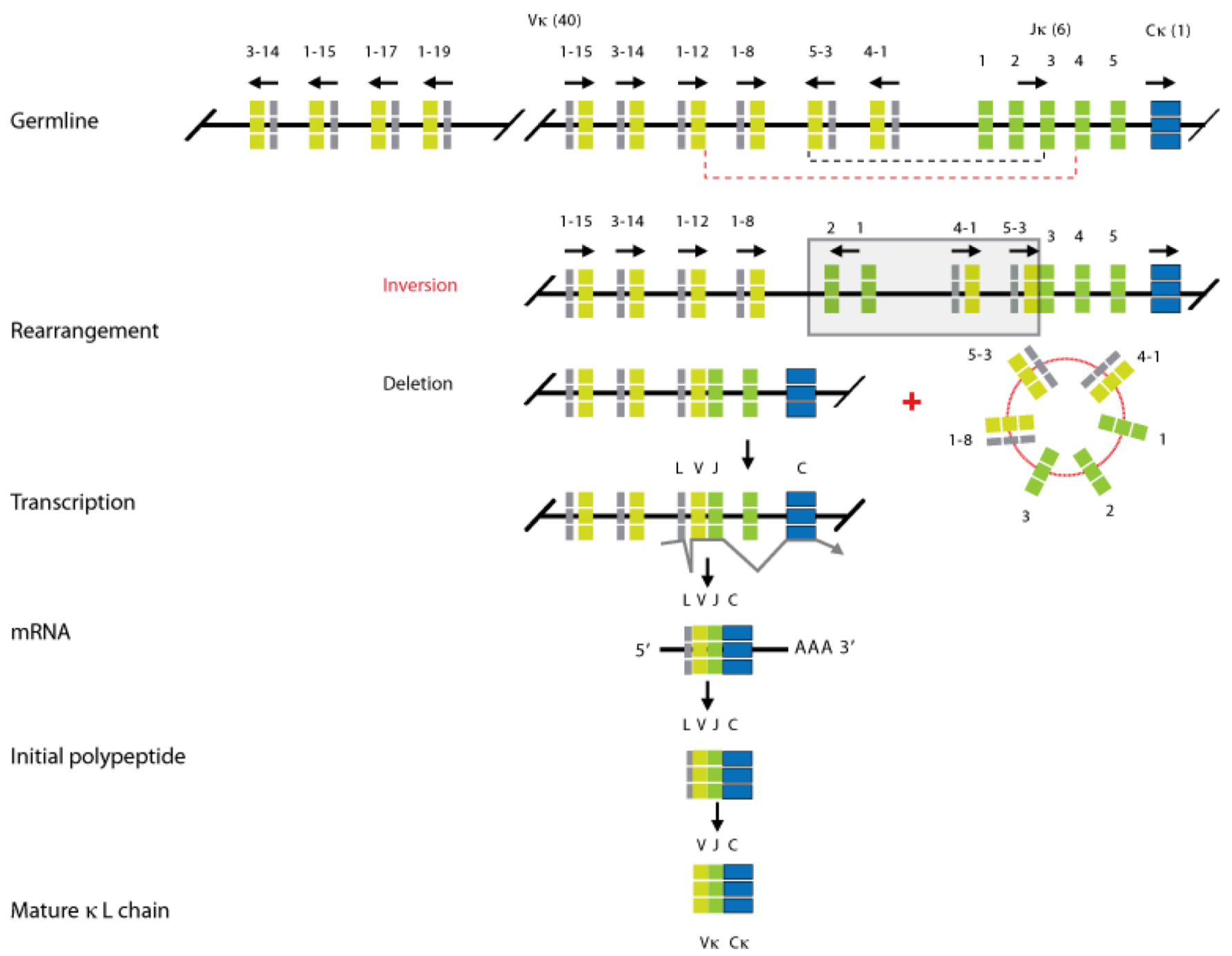

Figure 2. Rearrangement events in the human $x$ locus See text for further details. 
Ig Hchain Locus

Chr. $14 \mathrm{q} 32.2$

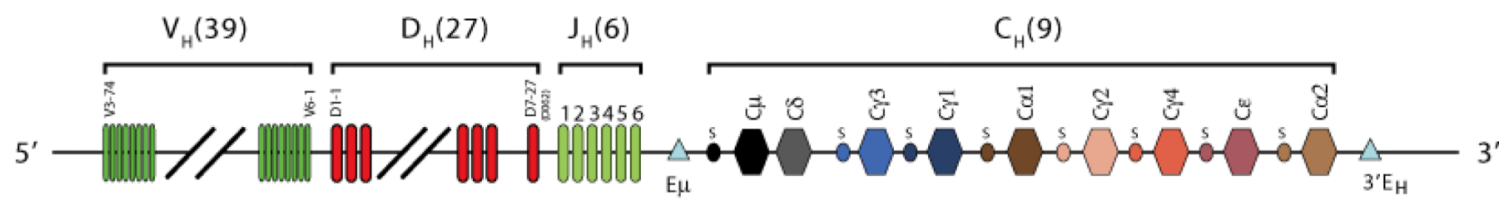

$\lg \kappa$ chain Locus

Chr. $2 \mathrm{q} 1.2$

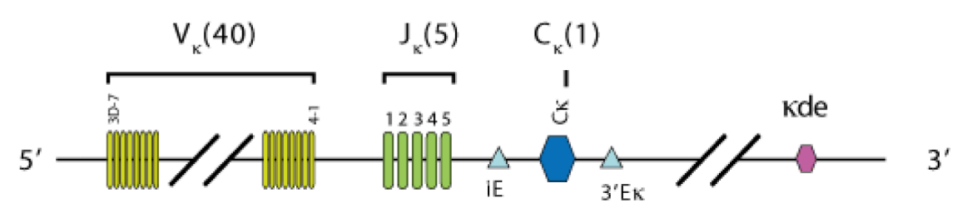

$\lg \lambda$ chain Locus

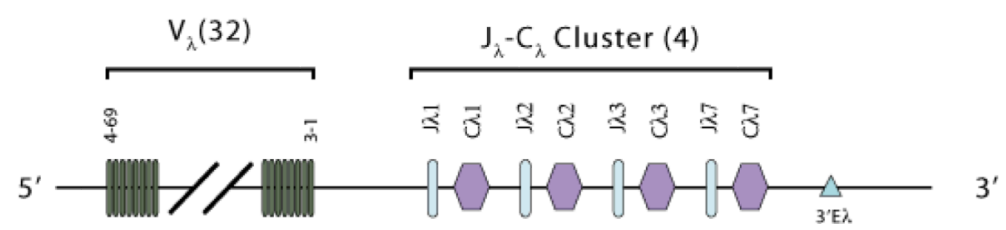

Figure 3. Representation of the chromosomal organization of the $\operatorname{Ig} \mathrm{H}, \boldsymbol{\kappa}$, and $\boldsymbol{\lambda}$ gene clusters The typical numbers of functional gene segments are shown. The $\kappa$ gene cluster includes a $\kappa$ deleting element that can rearrange to sequences upstream of $\mathrm{Ck}$ in cells that express $\lambda$ chains, reducing the likelihood of dual $\kappa$ and $\lambda$ light chain expression. 

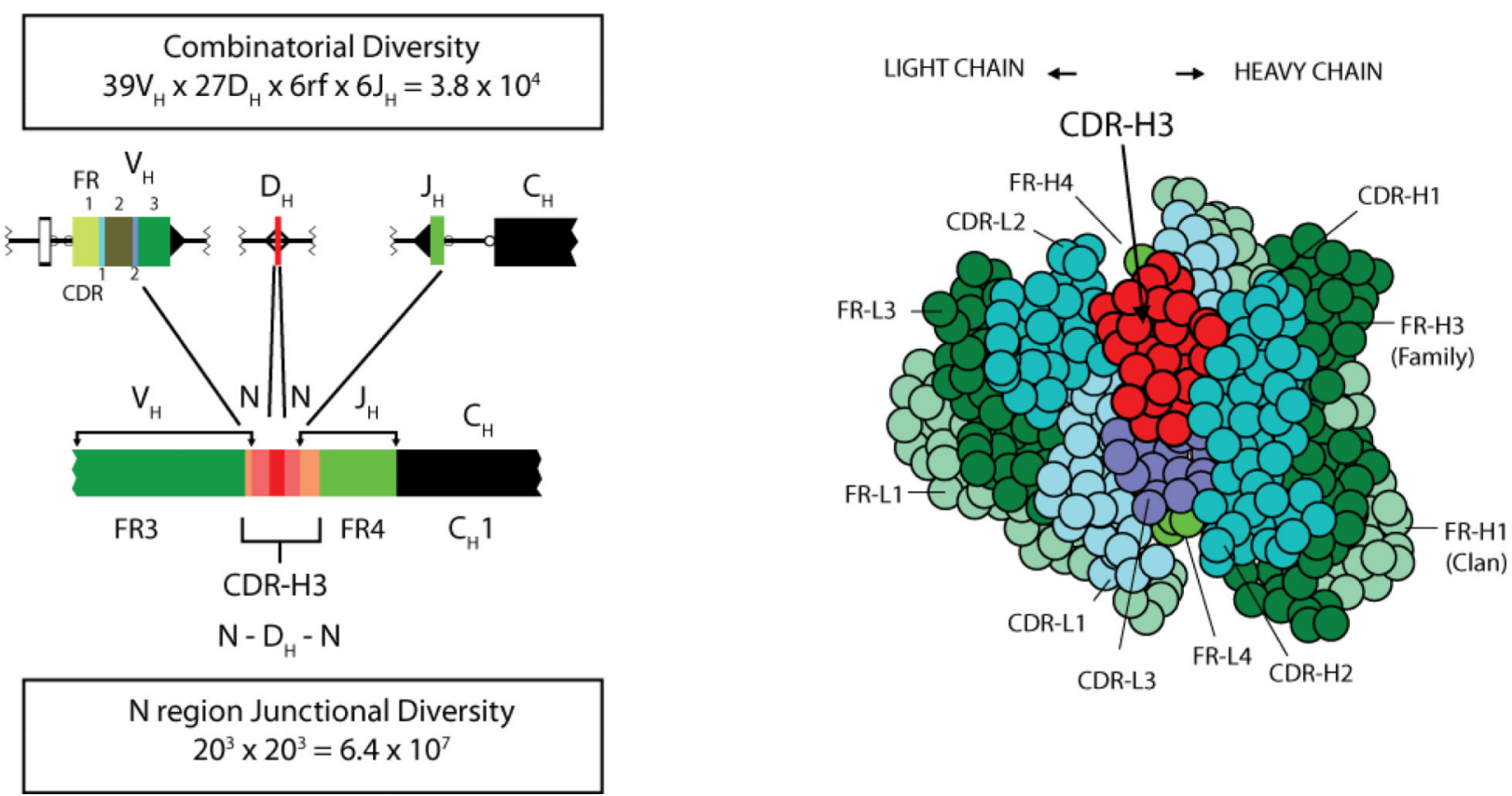

Figure 4. The antigen binding site is the product of a nested gradient of diversity (A) $\mathrm{H}$ chain rearrangement can yield as many as 38,000 different VDJ combinations. The addition of nine $\mathrm{N}$ nucleotides on either side of the $\mathrm{D}$ gene segment yields can yield up to 64,000,000 different CDR-H3 junctional sequences. (B) The view is looking into the binding site as an antigen would see the antigen binding site. This site is created by the juxtaposition of the three CDRs of the $\mathrm{H}$ chain and the three CDRs of the light chain. The $\mathrm{V}_{\mathrm{H}}$ domain is on the right side. The central location of CDR-H3, which due to $\mathrm{N}$ addition is the focus for repertoire diversity, is readily apparent. 


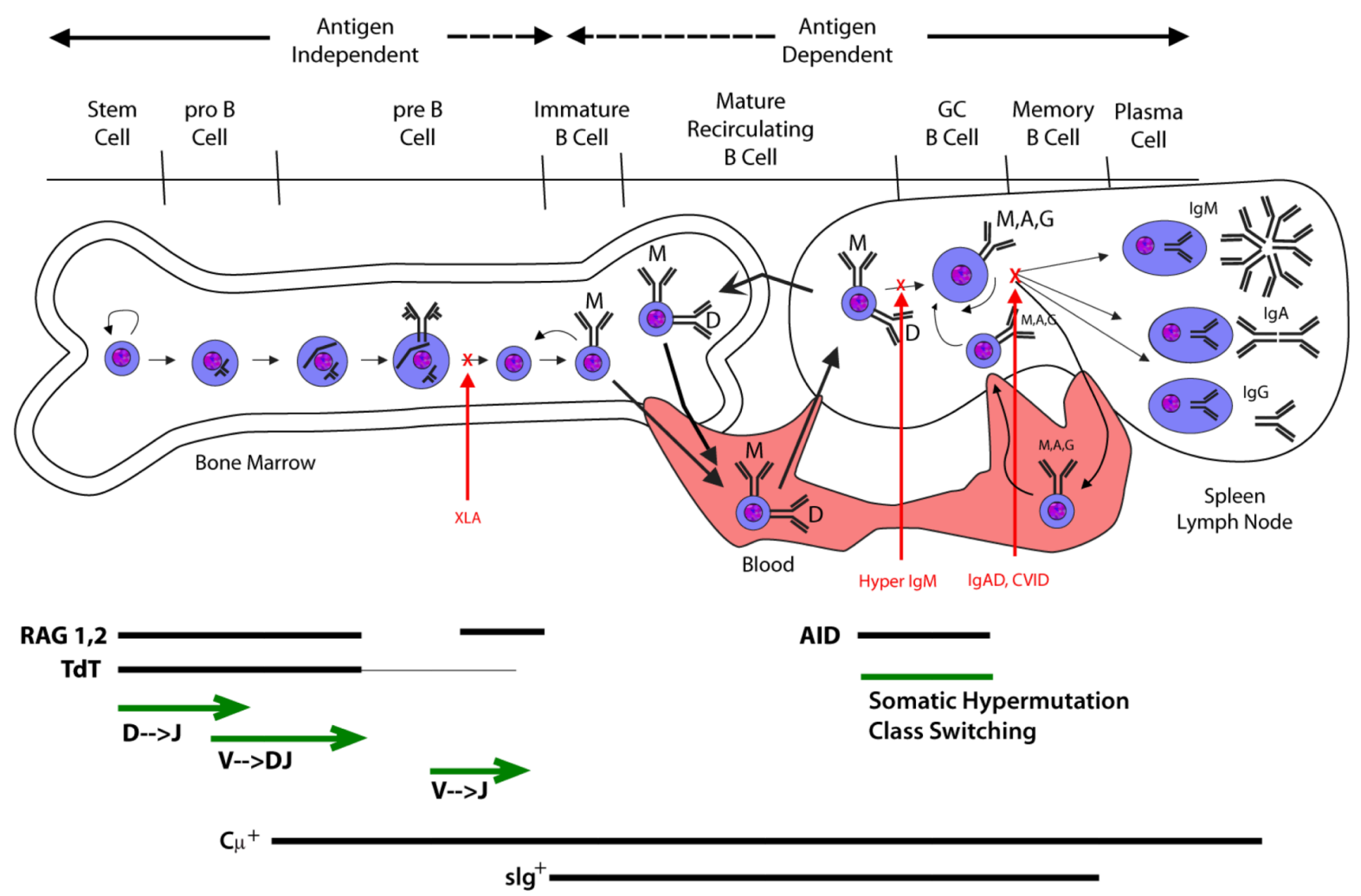

Figure 5. Immunoglobulin diversification and B cell development

Cartoon illustrating B cell development as a function of immunoglobulin rearrangement and modification. After birth, B cell development begins in the bone marrow and is independent of antigen stimulation. The pre-B cell is defined by the presence of cytoplasmic $\mu$ protein $\left(\mathrm{C} \mu^{+}\right)$. With development, the fate of the B cell becomes increasingly dependent on its response to antigen. Immature B cells leave the bone marrow and begin to express IgD. They recirculate through the blood, the secondary lylmphoid organs and the bone marrow. Encounter with cognate antigen can cause the cell to become a memory B cell or a plasma cell. Patients with X-linked agammaglobulinemia (XLA) lack BTK function and have difficulty making immature B cells and IgM. Patients with hyper IgM syndrome (Hyper $\operatorname{IgM})$ are unable to class switch. Patients with selective IgA deficiency (IgAD) or common variable immune deficiency (CVID) can class switch, but have difficulty becoming plasma cells or memory B cells. 

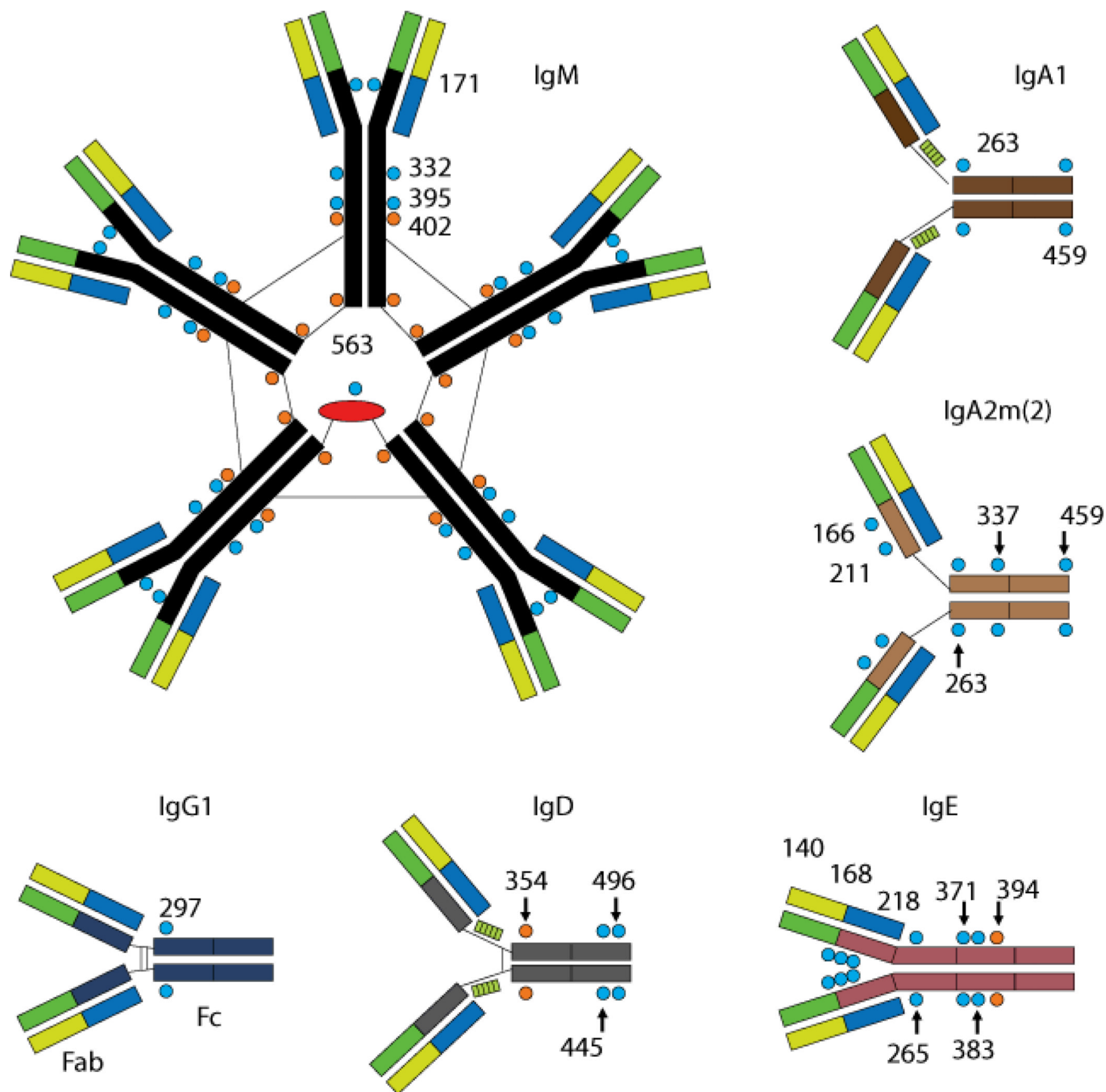

Figure 6. Structural and glycosylation properties of immunoglobulins Depiction of the structure and glycosylation sites (indicated by amino acid location) for human $\operatorname{IgM}, \operatorname{IgG}, \operatorname{IgD}, \operatorname{IgE}$ and $\operatorname{Ig} \mathrm{A} 2$ and $\operatorname{Ig} \mathrm{A} 2$. Adapted from.(28) 


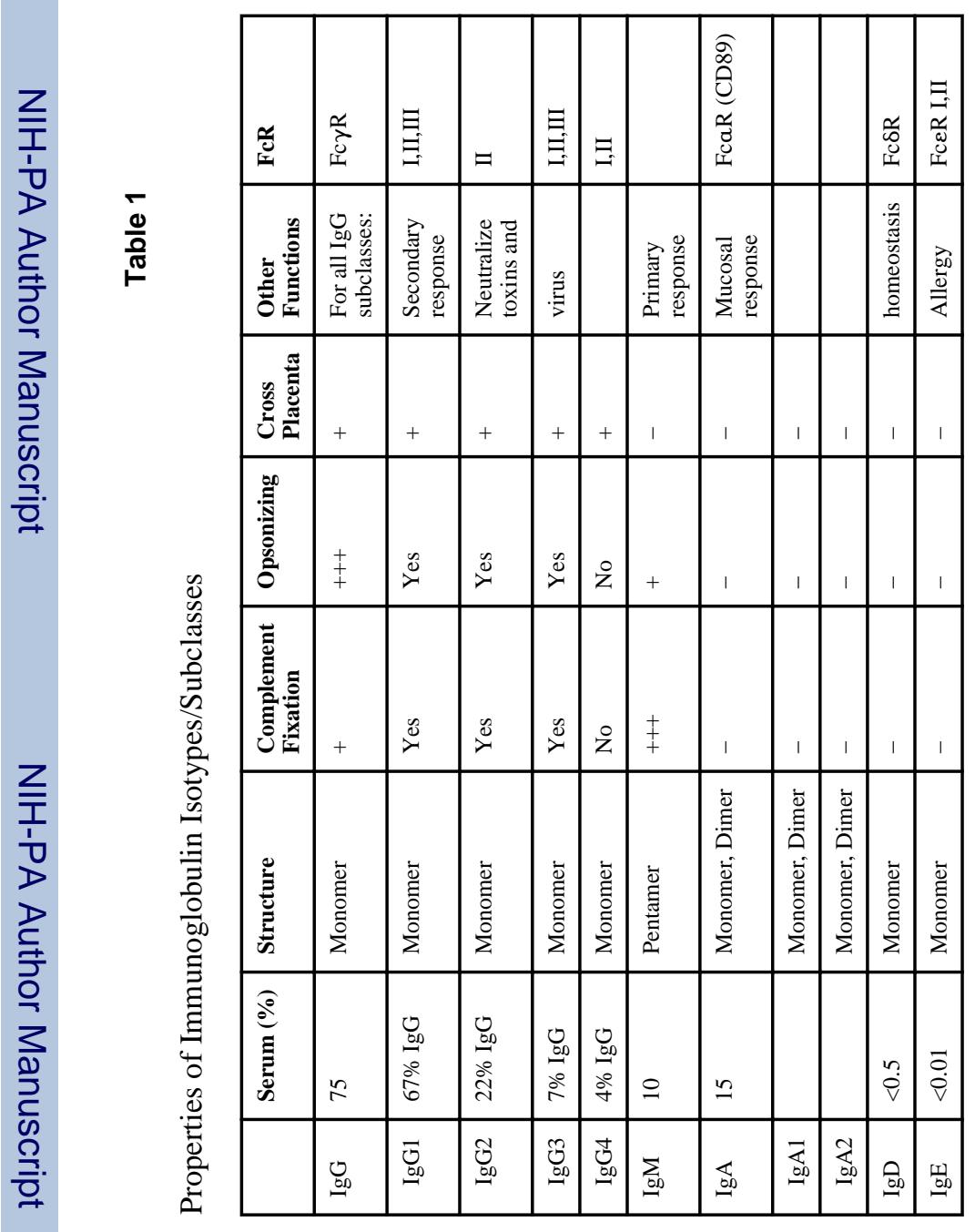

J Allergy Clin Immunol. Author manuscript; available in PMC 2013 June 03. 